\title{
Original Research \\ Corporate social responsibility in countries with mature and emerging pharmaceutical sectors
}

\author{
Anna VOLODINA, Sylvia SAX, Stuart ANDERSON. \\ Received (first version): 19-Mar-2009 Accepted: 12-Sep-2009
}

\begin{abstract}
${ }^{*}$
In recent decades the concept of Corporate Social Responsibility (CSR) has been adopted by many business sectors, including the pharmaceutical industry. However, in this and other sectors its application remains variable, particularly between mature and developing economies. Its stakeholders include pharmacy and medical students, their attitude to the involvement of companies in socially responsible activities will be important determinants of public response to the industry.

Objective: To investigate the knowledge, attitudes and practices of senior medical and pharmacy students towards the CSR concept in the pharmaceutical sector in mature (Germany) and developing (Russia) markets.

Methods: A questionnaire survey was carried out among senior pharmacy and medical students during the summer semester 2008 in two Russian and one German university. In each country 120 questionnaires were distributed. The response rate was $95 \%$ in Russia and $93 \%$ in Germany.

Results: Although the relevance of CSR was widely acknowledged by the students, very few were aware of CSR practices currently performed by companies. The reputation of the pharmaceutical industry was generally poor: less than $15 \%$ of respondents gave credence to the information provided in advertisements and fully supported pricing strategies as well as policies towards the developing countries. When choosing an employer more than $90 \%$ of respondents consider the policies affecting an employee directly as pivotal. However, for a high proportion of students $(59 \%$ in Russia and $64 \%$ in Germany) socially irresponsible behavior by companies has a significant negative impact. Conclusions: This paper identifies practices which students believe should be a part of the CSR programmes for the pharmaceutical industry, and also some that should be abandoned. It recommends that corporate communication on CSR should be expanded. Key differences are seen in perceptions of students in Germany and Russia towards the extent of irresponsible actions and the variation between them.
\end{abstract}

\footnotetext{
*Anna VOLODINA. Master of Science in International Health (MsIH). Section Epidemiology and Biostatistics, Heidelberg University, Institute for Public Health. Heidelberg (Germany).

Sylvia SAX. Master of Public Health (MPH), International Public Health Consultant, evaplan Public Health Consult at the University of Heidelberg. Heidelberg (Germany). Stuart ANDERSON. PhD. Associate Dean of Studies. London School of Hygiene and Tropical Medicine, London (United Kingdom).
}

Keywords: Drug Industry. Social Responsibility. Russia. Germany.

\section{RESPONSABILIDAD SOCIAL CORPORATIVA EN PAÍSES CON SECTORES FARMACÉUTICOS MADUROS Y EMERGENTES}

\section{RESUMEN}

En las últimas décadas, el concepto de responsabilidad social corporativa (RSC) ha sido adoptado por muchos sectores empresariales, incluyendo la industria farmacéutica. Sin embargo, tanto en este como en otros sectores, su aplicación es variable, particularmente entre las economías maduras y en desarrollo. Entre los decisores se encuentran los estudiantes de farmacia y medicina, y su actitud ante la participación de las empresas en actividades socialmente responsables será un determinante importante de la respuesta del público ante la industria.

Objetivo: Investigar el conocimiento, actitudes y prácticas de los estudiantes de últimos años de farmacia y medicina sobre el concepto de RSC en los mercados farmacéuticos maduros (Alemania) y en desarrollo (Rusia).

Métodos: Se realizó una investigación entre estudiantes de últimos años de farmacia y medicina durante el semestre de verano de 2008 en dos universidades rusas y una alemana. En cada país se distribuyeron 120 cuestionarios. La tasa de respuesta fue del 95\% en Rusia y del 93\% en Alemania.

Resultados: Aunque la importancia de la RSC fue reconocida por los estudiantes, muy pocos conocía las prácticas de RSC actualmente realizadas por las empresas. La reputación de la industria farmacéutica era en general pobre: menos del $15 \%$ de los respondentes daba crédito a la información proporcionada en los anuncios y apoyaba completamente estrategias de precios así como políticas para países en desarrollo. Cuando seleccionaban un empleo, más del $90 \%$ de los respondentes consideró las políticas que afectan al empleador como críticas. Sin embargo, para una alta proporción de estudiantes (59\% en Rusia y $64 \%$ en Alemania) las actitudes socialmente irresponsables de las empresas tenía un significativo impacto negativo.

Conclusiones: Este artículo identifica las prácticas que los estudiantes creen que deberían formar parte de los programas de RSC de la industria

farmacéutica, así como los que deberían abandonar. Se recomienda que se aumente la comunicación corporativa sobre la RSC. SE han visto diferencias 
clave en la percepción de los estudiantes en Alemania y Rusia sobre la extensión de las acciones irresponsables y la variedad de ellas.

Palabras clave: Industria farmacéutica. Responsabilidad social. Rusia. Alemania.

\section{INTRODUCTION}

The concept of Corporate Social Responsibility (CSR) is now well-established in many European countries although it remains contested and controversial in some places. The European Commission defines CSR as 'a concept whereby companies integrate social and environmental concerns in their business operations and in their interactions with their stakeholders on a voluntary basis'. ${ }^{1}$ Beyond Europe, the USA and a few other countries its adoption remains limited and fragmented. CSR is an emerging practice in most transitional countries, including Russia.

Earlier definitions emphasized the moral nature of CSR. In their review of the changing nature of business ethics Kilcullen and Koolstra defined CRS as 'the degree of moral obligation that may be ascribed to corporations beyond simple obedience to the laws of the state'. ${ }^{2}$ CSR had its origins in the 1950s in ideas about the social obligations of corporations; corporate decision making should be determined by societal values within specific realms, such as economic and legal. ${ }^{3}$ The idea of CRS as 'stakeholder obligation' resulted from acceptance that businesses should be answerable only to those who 'directly or indirectly affect or are affected by a firm's activities.' Stakeholder obligation typically extends to individuals and organizations (employees, customers and suppliers), communities (local residents and special interest groups), regulators and the media.

The concept has received considerable attention from researchers investigating the activities of corporations in a range of sectors, most notably tobacco and chemicals. Palazzo and Richter demonstrated how large corporations are able to embrace and manipulate CSR in ways that promoted their own business aims; tobacco companies have to deny damaging aspects of their past behavior, and present themselves as reformed and enlightened as part of the CSR strategy. ${ }^{4}$ Hirschhorn similarly concluded that a socially responsible tobacco corporation was an oxymoron. ${ }^{5}$ The practices and consequences of corporate social responsibility by a tobacco company in a developing country have been vividly described by Barraclough and Morrow. ${ }^{6}$ A more positive impact of CSR in the chemical industry has been described by Givel. ${ }^{7}$

To date CSR in the pharmaceutical sector has received only limited attention from researchers, although industry publications have considered the issue at length. Dukes devotes a section to it in his book on the law and ethics of the pharmaceutical industry $^{8}$, along with a chapter on the relationship between the industry and the developing world. He states that within this sector business and health interests often run in parallel, but that they can also diverge and conflict with one another. He examines major ethically-questionable activities of pharmaceutical companies, including the disproportionate spending of earnings on marketing, vaguely defined relationships with medical professionals, and the inappropriate setting of research agendas.

\section{Corporate Social Responsibility in the pharmaceutical sector}

Due to the number of ethical issues associated with pharmaceutical business and the vulnerability of the people to its products, CSR has a high relevance for pharmaceutical companies. Traditional market forces of supply and demand cannot always be applied to pharmaceutical products, since:

Patients cannot really make a choice whether to buy drugs or not.

- Patients cannot usually make informed choices about which particular drug to buy. They have to trust the opinions of health professionals such as doctors and pharmacists.

- The consequence of not having access to drugs, or not being able to buy a drug, is very often a question of life and death.

Since in most countries pharmaceutical companies operate within the private sector, making profits for their stakeholders by developing and selling medicines is their core business. Adoption of the CSR concept can, however, influence how medicines are sold, which pricing strategies are used, and how reasonable they are in a specific country setting.

Today, pharmaceutical sector CSR is practiced mainly by the multinational pharmaceutical enterprises originating in the USA and the European Union, often collectively referred as Big Pharma. The situation for the German pharmaceutical industry is typical of the situation for CSR in the pharmaceutical industry in Europe generally, due to uniform regulatory standards, common European agreements on CSR, and high levels of merger within the pharmaceutical industry.

Since CSR is a voluntary engagement, each company decides individually on the scope of its CSR activities. They can be classified according to whether they target the local community, employees or the environment. Currently, pharmaceutical companies demonstrate social engagement in the following ways:

- Donations and sponsorships: these include a variety of community and environmental projects as well as humanitarian aid to the developing countries.

- Promotion of research: companies establish private research institutes/foundations, and provide grants and scholarships to support young scientists.

- Introduction of environmentally friendly technologies.

- Establishment of voluntary political action committees. 


\section{Advocacy of human rights.}

So far there appears to be no unified approach to CSR in the pharmaceutical sector, as there is no agreement between relevant stakeholders and the industry on the scope of socially responsible practices by pharmaceutical companies. ${ }^{9,10}$ This lack of a common CSR philosophy means that activities of particular companies are often shortterm and inconsistent, which hinders evaluation of the CSR impact of the industry on both the community and the environment. ${ }^{9}$

\section{Corporate Social Responsibility in mature and emerging markets}

The CSR concept underwent a long way of developing and standard setting at the international level. An important step in the development of CSR was the Lisbon Summit in 2000. It was organized in order to discuss controversial issues of globalization and rapid technological development that shifted the world economy. ${ }^{11}$ During this Summit the European Council appealed to business to do more to meet the CSR goals. The result of this summit was a Green Paper on $\mathrm{CSR}^{12}$ which was followed by Commission Communication on CSR. ${ }^{13}$

Since then the European Commission has continued to promote the CSR agenda by developing key policy documents, supporting publicprivate partnerships and research, and raising awareness through forums and publications. In 2002 the First European Multi-Stakeholder Forum on Corporate Social Responsibility was established. Finally, the Millennium Development Goals, formulated within the United Nations Development Program in 2003 serve as a compass for business in developing CSR programmes.

There have to date been few if any studies that have compared the implementation of the CSR concept between developed and transitional countries. The countries of Europe have mature pharmaceutical sectors and mature legal and ethical frameworks. Transitional countries undergoing transformation from social to market economies have transitional pharmaceutical sectors and often incomplete and imperfect legal and ethical frameworks. In Russia, for example, market economy principles were first introduced in 1991 and the pharmaceutical market only recently has entered a phase of rapid growth. ${ }^{14}$ It will take some time before it reaches the same level of maturity as the German market. ${ }^{15}$

Current economic and social forces driving the development of CSR in Europe have not had the same degree of influence in Russia. Awareness amongst business leaders, government officials and civil society about the CSR concept is very low, a situation confirmed by research conducted by the Association of Managers in Russia in 2002-2005. ${ }^{15}$ Company executives in the pharmaceutical sector believe that obstacles to the successful implementation of CSR include a lack of a legal framework for philanthropic activities and undefined boundaries of business engagement. ${ }^{16}$ Many observers note that an accurate understanding of the CSR framework for business development is inherent in mature companies with well-established corporate cultures. ${ }^{14}$ The challenge for CSR in the evolving pharmaceutical sector in Russia is to scale up existing initiatives and to raise awareness amongst all stakeholders in order to make this concept an essential part of business development.

\section{Awareness amongst students of Corporate Social Responsibility}

Medical and pharmacy students are important stakeholders for pharmaceutical companies. By promoting and prescribing medicines, by influencing research and development (R\&D) priorities, and by advising customers in drug stores, future physicians and pharmacists will have an important impact on the pharmaceutical industry, as well as on the health of people, in the near future. Their perception of CSR-associated responsible practices and their ability to see the long-term impact of private sector business activities will directly contribute to the further development and promotion of the CSR concept by pharmaceutical companies.

Several studies of the awareness of ethical issues by pharmacy and medical students have been reported. Latif and Berger carried out an extensive study of moral reasoning amongst pharmacy students and community practitioners in America. ${ }^{17}$ They found significant group differences in moral reasoning, and concluded that the community pharmacy setting may in fact hinder moral development in relation to the practice of pharmacy. In their review of the scope of pharmacy ethics Wingfield, Bissell and Anderson concluded that research was required into how best to teach and assess ethical competence before practice, and into the degree of influence that the business environment has on the value system of pharmacists. ${ }^{18}$ Yet little is currently known about the knowledge and attitudes of pharmacy students to a range of subjects which present such dilemmas.

The main aim of this study is to describe the knowledge, attitudes and practices of senior pharmacy and medical students in an industrialized (Germany) and a transitional (Russia) society respectively, concerning the CSR concept in the pharmaceutical sector. The two countries were studied in order to understand and compare perceptions amongst students in the mature (German) and the developing (Russian) pharmaceutical markets respectively.

The study has the following specific objectives:

1. To determine the knowledge of the students about the CSR concept and socially responsible activities currently performed by pharmaceutical companies in Russia and Germany;

2. To identify the factors perceived as essential for socially responsible pharmaceutical companies;

3. To investigate the reputation of the pharmaceutical industry amongst senior pharmacy and medical students in Russia and Germany;

4. To estimate the extent to which the CSR concept influences the professional practices of students, such as choice of employers or partners for professional cooperation. 


\section{METHODS}

The study design was a cross-sectional study, which included descriptive and comparative components. The descriptive component focused on the definition of a socially responsible pharmaceutical company given by the students and the importance of the CSR concept for them as potential employees. The comparative aspect included knowledge of current CSR practices and attitudes towards the pharmaceutical industry amongst the students in these two regions. Russia and Germany were selected as examples of countries with transitional and mature economies by convenience. The setting for the study was the University of Heidelberg in Germany and two Universities in Russia: the State Medical Academy and Voronezh State University, both located in the city of Voronezh. The research proposal was approved by the Ethics Committees of both the Department of Tropical Hygiene and Public Health of the University of Heidelberg and by the Pharmaceutical Department of the Voronezh State University. Selection of the students was done through purposive homogeneous sampling. The criteria for selection were as follows:

- enrolment in the medical or pharmaceutical faculty of the participant universities;

- full-time tuition;

- completion of at least 4 years of study in medicine or pharmaceutical science.

The final year of undergraduate study was chosen as a selection criterion since after four years of study medical and pharmacy students usually have sufficient knowledge of their future fields of practice, related public health issues and the responsibilities and position of the pharmaceutical industry in the health sector to make informed decisions about their futures. Senior students are also more likely to identify their expectations concerning the activities of potential employers. Other respondent characteristics such as gender and age were not controlled.

Methods of data collection included a questionnaire survey, conducted at the universities during the spring semester, 2008. A survey questionnaire was developed in English and translated into Russian and German. It was based on questions emerging from the literature review and on the similar survey instruments used to assess the social image of different industrial sectors. The questionnaire consisted of seventeen questions, the first of which was open-ended; the others included closed-ended questions, multiple choice questions, and scaling questions to collect quantitative data.

Students were asked to fill out the questionnaires at the beginning of their morning lectures; the time required was specifically allocated by teaching staff. Before every questionnaire completion exercise the researcher explained in Russian or in English the purpose of the study, reassured students about its confidentiality, and indicated the time required to complete it. In each country 120 questionnaires were distributed, 60 for each of the four faculties across the two countries. The response rate was $95 \%$ in Russia and $93 \%$ in Germany.
The quantitative data obtained from the study was analyzed using the Epi Info software package. An open-ended question about socially responsible practices of pharmaceutical companies was analyzed manually using the method of inductive content analysis.

\section{RESULTS}

\section{Objective 1: Knowledge of the CSR concept and current practices}

In order to assess their knowledge about CSR in the pharmaceutical industry, the students were first asked to define a socially responsible pharmaceutical company. The aim of this question was to encourage students to give their own ideas and to express their opinions about the topic before they moved on to the closed questions. $84 \%$ of Russian and $71 \%$ of German students were able to define activities that they perceived to be socially responsible for pharmaceutical companies; overall $23 \%$ of the respondents did not complete the question or wrote "I do not know"/"| have never thought about it". A majority $(80 \%)$ of the Russian students stated that a socially responsible pharmaceutical company was one that ensured a fair salary, high labor standards, career opportunities and offered social guarantees such as medical insurance, paid holidays and pension. Less than $20 \%$ of these Russian students mentioned responsible activities aimed at society or the environment, such as investment in environmentally friendly technologies or community development projects.

Similar results were obtained for the German students: $70 \%$ rated activities directed towards employees most highly. A substantial proportion of the respondents, $30 \%$, indicated in general terms that responsible pharmaceutical companies should be "less profit-orientated," and should have a sense of responsibility towards society, without specifying any particular activities. Less than $15 \%$ of German students mentioned support for humanitarian projects in developing countries, or having high ethical standards for the conduct of clinical trials.

To assess the level of knowledge about current CSR performance of pharmaceutical companies students were asked if companies operating in their countries included CSR activities in their business operations, and if yes to name the companies. $60 \%$ of German and $59 \%$ of Russian students stated that they did not know whether pharmaceutical companies undertook any activities specifically designed to benefit employees and society, defined by the students as socially responsible activities. Very few of those who did claim to know of these activities could name a company delivering them.

Knowledge of current CSR practices of pharmaceutical companies in the area of environmental protection was also low amongst all respondents. $70 \%$ of German and $60 \%$ of Russian students stated that they did not know whether pharmaceutical companies, operating in their countries, took actions to protect the environment. $32 \%$ of students in Russia thought that 
pharmaceutical companies did not do anything in this area; in Germany this opinion was held by $14 \%$ of students. An example of a pharmaceutical company currently addressing environmental problems in its business operations was given by only $5 \%$ of all respondents.

\section{Objective 2: Essential Factors for CSR in the pharmaceutical industry}

We were interested in students' opinions about the importance of socially responsible practices for the pharmaceutical industry. This interest came from the fact that the boundaries of CSR in this particular industry are vague, and its necessity is often questioned in the literature. ${ }^{19}$ Firstly, students were asked to indicate their level of support for the statement: 'besides profit-making, a pharmaceutical company should also be actively engaging itself [in activities] for the good of the society in which it operates'. Students selected a response from 'fully agree', 'partly agree', 'disagree entirely' or 'I do not know'. The results indicated that the need for the pharmaceutical industry to have clear CSR policies is seen as very important by students in both countries. 92\% of Russian and 95\% of German students fully or partly agreed with this statement. Only 5\% of respondents in Russia and 4\% in Germany disagreed entirely; the remaining respondents answered 'I do not know'.

Secondly, we analyzed students' opinions about the importance of socially responsible practices as compared to regular business operations. We collated a number of activities that were identified in the literature as being essential for the pharmaceutical industry, and asked students to rate them according to their perceived importance. The list of activities included both socially responsible practices, such as drug donations and development projects, and purely business activities, such as research and development (R\&D), drug production, and marketing. Students ranked the activities on a scale ranging from 'essential', 'important', 'somewhat important' to 'not important'.

Students in both countries had comparable priorities. The top five activities (of ten), ranked by respondents in both countries as 'essential' or 'important' for the pharmaceutical industry were very similar (percentage of students giving this answer in brackets):

Russian students:

1.Providing comprehensive information on the company's products (95\%);

2.Ensuring drug safety/quality (94\%);

3.Subsidizing treatment for the company's employees $(90 \%)$

4.Undertaking research and development (87\%);

5.Marketing and selling medicines (86\%).

German students:

1.Ensuring drug safety/quality (97\%);
2.Undertaking research and development (97\%);

3.Providing comprehensive information on the company's products $(88 \%)$;

4.Subsidizing treatment for the company's employees (87\%);

5.Undertaking drug production (84\%).

Socially responsible activities (such as supporting vulnerable populations with subsidized medicines, and community development projects) were at the bottom of the priority lists in both countries; on average they received support from $63 \%$ of Russian and $65 \%$ of German students.

\section{Objective 3: Reputation of pharmaceutical industry amongst students}

To assess the reputation of the pharmaceutical industry amongst medical and pharmacy students in both countries, we asked the question: "Do pharmaceutical companies generally do a good job by serving people today?"

$38 \%$ of German and $55 \%$ of Russian students answered positively to this question; however, $40 \%$ of students in Germany and $23 \%$ in Russia were not sure about the impact of pharmaceutical companies on society. $22 \%$ of the students in each country responded that pharmaceutical companies do not do a good job by serving people and society in general.

To further analyze the image of pharmaceutical companies amongst the students, we included a number of questions regarding the current activities and policies of the companies. Students were asked to choose their level of support for several positive statements about pricing, marketing and support of developing countries. The results for students' opinion on current practices are presented in Figures 1, 2 and 3.

\section{Objective 4: Impact of pharmaceutical company} CSR on choice of employer

One of the questions in this research study was designed to assess the extent to which the reputation of pharmaceutical companies in the area of corporate social responsibility influences medical and pharmacy students in their employment choices, or their decisions to cooperate with the pharmaceutical industry in areas such as research and training. Students were asked to rank the importance of a number of characteristics in a potential employer in making their decision. Some of these characteristics reflected socially responsible policies of a company, such as using environmentally friendly technologies or participating in the life of the community. Other factors were purely business-oriented and affected an employee directly, for example financial reward or interesting area of work. Figure 4 summarizes the number of students indicating 'essential' and 'important' ranking for each of the factors. 


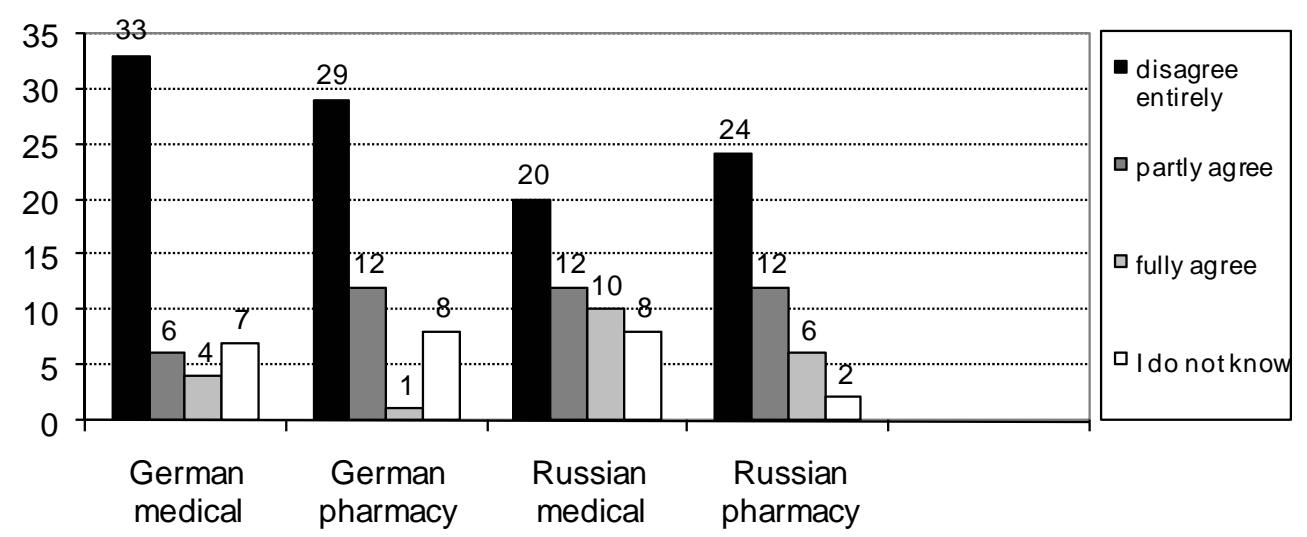

Figure 1: Support for the statement "Pharmaceutical companies use fair pricing strategies when marketing their products"

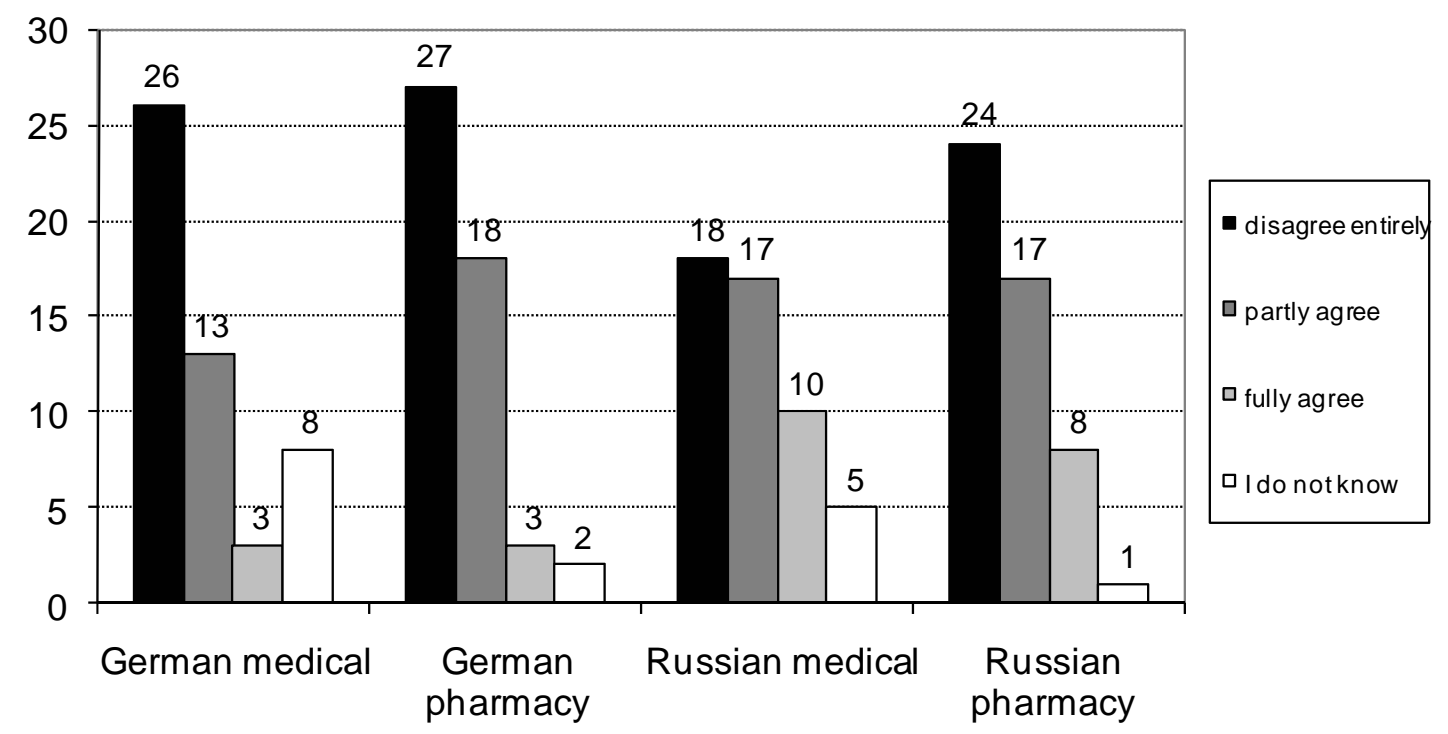

Figure 2: Support for the statement: "Pharmaceutical companies provide true information on their products in advertisements and promotional campaigns"

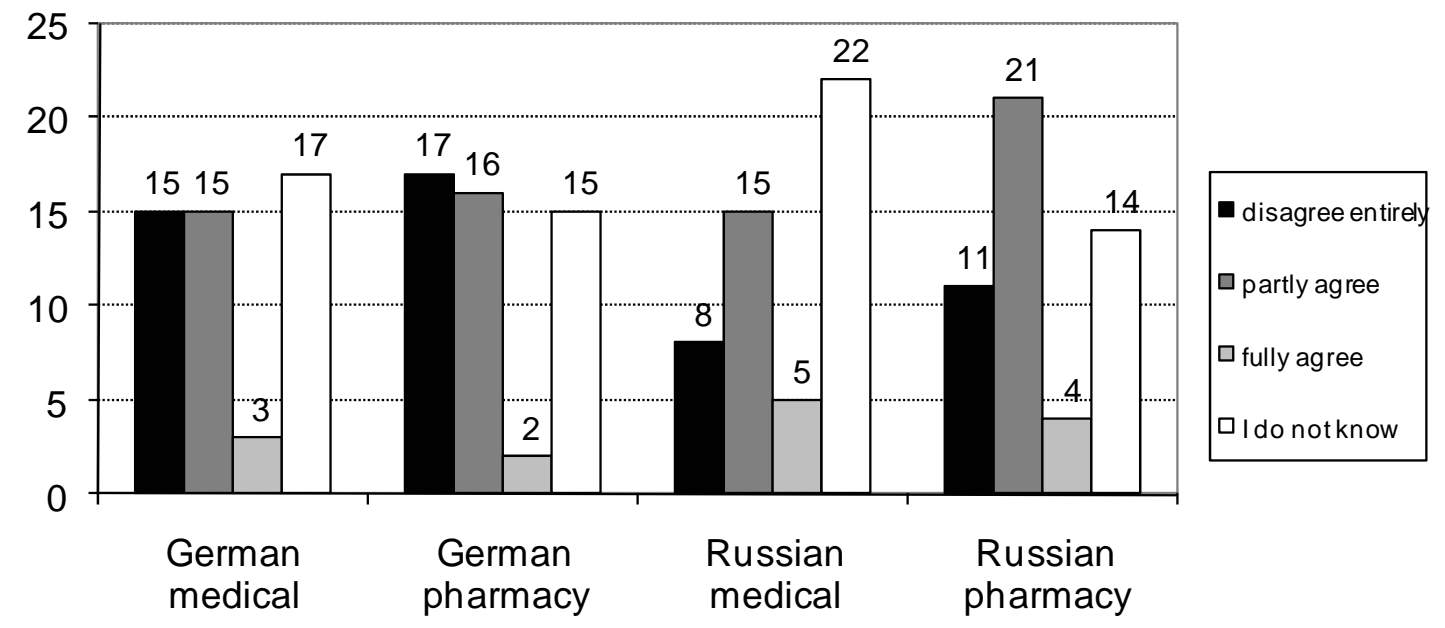

Figure 3: Support for the statement "Pharmaceutical companies take actions to improve the health of people in developing countries" 


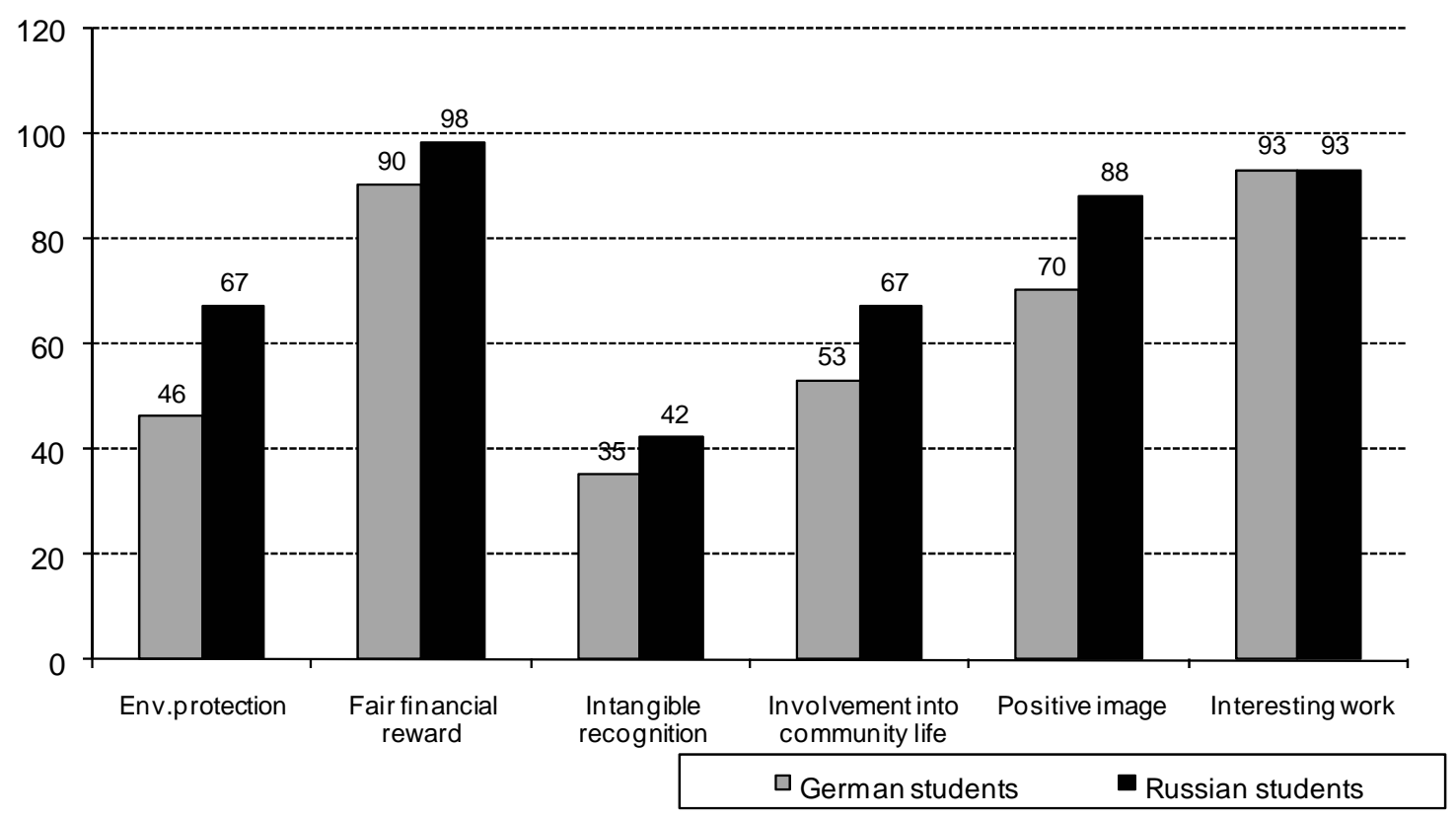

Figure 4: Factors identified by German and Russian students as essential or important in choosing a pharmaceutical company as a potential employer

Following analysis of further questions we identified three main reasons for pharmacy and medical students in Russia and Germany to consider moving from a particular pharmaceutical company as their employer. For Russian students these were (percentage of students giving this answer in brackets):

1.Low financial reward (96\%);

2.No career development/lack of interest in the work (91\%);

3.Poor working environment (78\%).

The main factors that could motivate German medical and pharmacy students to change a pharmaceutical company as employer were:

1.No career development/lack of interest in the work $(96 \%)$;

2.Poor working environment (95\%);

3.Low financial reward (87\%).

However, the number of students who considered the lack of policies on corporate social responsibility to be an important reason for changing an employer was surprisingly high. The three main areas of socially irresponsible activities for students in Russia were as follows (percentage of students giving this answer in brackets):

1.No transparency within the company (64\%);

2.Engagement of a company in a court case $(64 \%)$; 3.Environmental pollution of my country/city (51\%).

The three main reasons ranked by German students as important were:

1.Environmental pollution of my company/city (70\%);

2.Engagement of a company in a court case (51\%); 3.Negative image of a company in the media (38\%).

\section{DISCUSSION}

This study has shown that medical and pharmacy students in both Germany and Russia have a general understanding of the CSR concept and business activities related to it. Their definitions of a socially responsible company were in line with those found in the literature. They recognize the relevance of CSR for the pharmaceutical industry, and this must be an important factor in future discussions about the relevance of CSR to the industry. However, students' definitions of a socially responsible pharmaceutical company mainly refer to employment policies; the societal and environmental dimensions of the CSR concept are generally missing. Indeed, there appears to be a tendency for pharmacy and medical students to equate CSR with good employment practices. Whilst these are clearly important this tends to suggest that students are more concerned with their own personal well-being than with wider societal and environmental issues.

Indeed, pharmacy and medical students in both countries appear to make no clear distinction between CSR and employment practices. Yet this is a distinction between what companies choose to do voluntarily and what they are obliged to do in order to comply with the law. On the other hand they appear to make a clear distinction between corporate social responsibility and corporate social irresponsibility. For the industry the impact of any practices that are perceived to be socially irresponsible, such as pollution or unreasonable pricing policies, can easily outweigh any benefits that might accrue from investment in CSR practices. 
The fact that students attach great importance to responsible policies towards employees, but omit companies' contributions to community and safe environments, could reflect their position as future employees. This supports previous observations on the association between the perception of the CSR concept and the position of the stakeholder ${ }^{1,20}$ and emphasizes the importance of engaging all relevant stakeholders in an open dialogue in order to develop firm commitments to CSR polices by a company or industry sector. ${ }^{21}$ However, it could also reflect the fact that students are not clear about the scope of CSR and its implementation mechanisms for the pharmaceutical industry in either country.

When rating the importance of different activities performed by the pharmaceutical industry, students in both countries give priority to traditional pharmaceutical business practices, such as production and the marketing of medicines. Recognition of CSR activities is rated as of secondary importance, although the number of students who consider them to be important is quite high. This indicates that, for our study groups, full implementation of the CSR concept in the pharmaceutical sector could be carried out without undermining core responsibilities of the industry, and would not be to the detriment of financially profitable activities undertaken by the industry.

For successful implementation of CSR programmes it is important that stakeholders, and society in general, understand the factors that limit the contribution of the pharmaceutical industry to public issues. Some activities, such as drug donation programmes and subsidies, may not become common CSR policies in many pharmaceutical companies $^{22}$, but companies may need to give further consideration to societal and environmental issues.

The level of knowledge about current CSR practices in pharmaceutical companies does not differ significantly between students in mature and transitional economies. We might reasonably expect that German students would be better informed about these issues, since our analysis shows that pharmaceutical companies operating in Europe are more active in the area of CSR. However, our research indicates that German students are in fact no better informed than their Russian counterparts. This could indicate that the current tools used by pharmaceutical companies to communicate CSR activities are not achieving their full potential, or that some stakeholders (such as pharmacy and medical students) are missing from the list of target audiences. Our research shows that CSR is clearly a meaningful component for the reputation-building strategies of companies, and that it would influence decisions taken by our study group. A deliberate and reasonable level of CSR communication can be used to enhance HR practices. $^{12}$ It appears that pharmaceutical companies have not so far fully utilized CSR policies to their advantage in gaining the support, trust and respect of the next generation of doctors and pharmacists.

CSR currently plays some part in influencing students' choice of potential employer; and it is reasonable to suggest that this influence will increase in the future. Our study shows that, out of six possible factors involved in choosing an employer, the leading ones are financial reward and interesting area of work. But at the same time a remarkable number of students attach considerable importance to the positive image of a company; this image undoubtedly has a CSR component.

Given the increasing world attention paid to environmental issues and globalization in general, we expect to see ever increasing attention paid by different stakeholders to the environmental policies and community engagement of the private sector. We believe that more information and further awareness of CSR issues by relevant stakeholders is needed. Increased sensitization to these issues may come from the companies themselves, as a component of human resources and public relations activities, or from other sources intended for relevant stakeholders. ${ }^{23}$

The role of universities is also key to dissemination of information about CSR and its mechanisms. ${ }^{24}$ At present CSR is taught in Business Schools and MBA programs in Russia and Germany, but not in medical and pharmacy schools. None of the curricula of the courses attended by our research participants included CSR. There is a rising expectation that professional staff recruited to pharmaceutical companies will be knowledgeable about $\operatorname{CSR}^{12}$, and it will become increasingly important for teaching about the CSR concept to be included in the curricula of these schools. Doing so is likely to have a significant impact on future leaders within the pharmaceutical and medical sectors.

One of the striking findings of this study was the discovery that support for the pharmaceutical industry and its business practices is low amongst medical and pharmacy students in both Germany and Russia. Moreover, in their appraisal of current practices of pharmaceutical companies, German students were especially critical. The roots of such low opinions about the pharmaceutical industry are most probably different in Germany and Russia. In Germany, where the market is strong and competitive, it may be a consequence of frequently publicized drug scandals, drug withdrawals, unclear relations with physicians, and criticisms of the industry by non-governmental organizations. ${ }^{25,26,27}$ The finding that companies should be "less market oriented" and "less profit driven", expressed by many German students, highlights the low level of trust in the activities of pharmaceutical companies amongst this group.

The tarnished image of pharmaceutical companies in Russia may reflect the difficulties of the transitional nature of the economy, when the role of business is not clear and governmental institutions are weak. A market economy was introduced in Russia two decades ago, and the Russian pharmaceutical industry has only recently become a significant sector where high profits are being reported. ${ }^{16}$ If companies in Russia learn from the experience of their western colleagues, and integrate CSR policies into their activities in the 
early stages of development, when corporate culture and the reputation of the industry are being shaped, it should help them to improve their image amongst a wide range of stakeholders, including pharmacy and medical students, and avoid potentially harmful actions (both to themselves as an industry and to society at large). Whatever the reasons for the low opinion and confidence in the pharmaceutical industry amongst students, it can have a far reaching impact on their future professional practices. In this study we addressed only the choices students make about employers and cooperation partners, but feeling good or bad about the company people work for has broader implications for job satisfaction, corporate climate, motivation and performance of the employees.

\section{CONCLUSIONS}

This study of CSR amongst medical and pharmacy students in two countries with different states of maturity of the pharmaceutical industry has demonstrated that medical and pharmacy students have a general understanding of the CSR concept, which, however, is determined to a large degree by their position as stakeholders. For CSR policies to become established in both countries, an appropriate educational approach to CSR, led by the universities, is needed.

Students' appraisal of business practices used by pharmaceutical companies in their home countries appears to be low, and this can influence their support and collaboration with the pharmaceutical industry in the future.
Pharmaceutical companies operating in Russia need to further develop and implement the CSR concept in their business operations. Since CSR is a new concept in Russia, at this stage it is necessary to collect and exchange the information about CSR and best-practices and to promote CSR initiatives. It will facilitate the sustainability of the pharmaceutical sector in the transitional economy. Multinational pharmaceutical companies operating in Germany could usefully revise their current practices in the light of the CSR concept adopted by European business forums and associations in order to improve their reputation among key stakeholders. They need to consolidate their efforts and develop uniform CSR strategies that will be feasible for the pharmaceutical industry and at the same time will meet the expectations of its key stakeholders.

There would appear to be scope for greater use of the CSR concept by the pharmaceutical industry in both countries in formulating their human resources policies and their reputation building strategies. Companies could usefully develop more comprehensive CSR communication mechanisms and diversify them with new tools, using a range of media including the internet, so as to include all relevant stakeholders and ensure continuing dialogue with them.

\section{CONFLICT OF INTEREST}

The authors have no conflict of interest to disclose with regard to this research.

1. Final Report: Final results and recommendations. European Multi Stakeholder Forum on Corporate Social Responsibility. [place, publisher, date unknown]. May 2004 [cited 2008 May 26]. 27 p. Available at: http://circa.europa.eu/irc/empl/csr_eu_multi_stakeholder_forum/info/data/en/CSR\%20Forum\%20final\%20report.pdf

2. Kilcullen M, Kolstra JO. At least do no harm: sources on the changing role of business ethics and corporate social responsibility. Ref Serv Rev. 1999;27(2):158.

3. Maignan I, Ferrell OC. Corporate social responsibility and marketing: an integrative framework. J Acad Mark Sci. 2006;34(2):158-166

4. Palazzo G, Richter U. CSR business as usual? The case of the tobacco industry. J Business Ethics. 2005;61:387-401.

5. Hirschhorn N. Corporate Social responsibility and the tobacco industry: hope or hype? Tobacco Contr. 2004;13:447-453.

6. Barraclough S, Morrow M. A grim contradiction: the practice and consequences of corporate social responsibility by British American Tobacco in Malaysia. Soc Sci Med. 2008;66 (8):1784-1796.

7. Givel M. Motivation of chemical industry corporate social responsibility through responsible care. Health Policy. 2007;81:85-92.

8. Dukes MNG. The law and ethics of the pharmaceutical industry. 2nd ed. London: Elsevier; c2005. Chapter 2.10: Corporate social responsibility and governments. pp. 109-123.

9. Esteban, D. Strengthening Corporate Social Responsibility in the Pharmaceutical Industry. J Med Mark. 2008;8(4):77-79.

10. Weyzig, F. (2004) Sector profile of the Pharmaceutical Industry. Amsterdam: Somo.

11. Single Market News (2000) The Lisbon Summit: Concrete Action to Stimulate European Competitiveness. Available at: http://ec.europa.eu/internal_market/smn/smn21/s21mn14.htm (Accessed: 19 May 2008).

12 European Union Green Paper (2002) Promoting a European Framework for Corporate Social Responsibility. Available at: http://www.jussemper.org/Resources/Corporate\%20Activity/Resources/greenpaper_en.pdf (Accessed: 15 April 2008).

13. European Union White Paper (2002) Communication concerning Corporate Social Responsibility: A Business Contribution to Sustainable Development. Available at:

http://www.jussemper.org/Resources/Corporate\%20Activity/Resources/sipade2.pdf (Accessed: 17 April 2008).

14. Mshvelidse, E. Investment in the Future. Pharm Rep. 2006;21(426):13-15.

15. Pharmacy reporter. Philanthropy in the pharmaceutical market. Pharm Rep. 2006a;21(4):29-30

16. Pharmacy reporter. Corporate Social Responsibility: what needs to be discussed. Pharm Rep. 2006b;11(62):2-4. 
17. Latif DA, Berger BA. Moral reasoning in pharmacy students and community practitioners. J Soc Admin Pharm.. 1997;14(3):166-179

18. Anderson SC, Huss R, Summers R, Wiedenmayer K. Managing Pharmaceuticals in International Health. 2nd ed. Basel, Switzerland: Birkhauser; c2005. Chapter 4, Managing Pharmaceuticals in International Health: Policy Initiatives and their Implications; p. 156-169. Available at: http://www.hillandknowlton.com/press/releases/2008/01/16/global-study-ofelite-mba-students (Accessed: 5 June 2008).

19. Freeman R, Liedtka, J. Corporate Social Responsibility: a Critical Approach. Business Horizons. 1991;34(4): 92-98.

20. United Nations Industrial Development Organization (UNIDO). Building linkages for Competitive and Responsible Entrepreneurship. [Internet]. 2007 [cited 2008 April 8] Available at: http://www.unido.org/fileadmin/import/69447_CSRI_08.pdf

21. European Union White Paper. Communication concerning Corporate Social Responsibility: A Business Contribution to Sustainable Development. [Internet]. 2002 [cited 2008 April 17] Available at: http://www.jussemper.org/Resources/Corporate\%20Activity/Resources/sipade2.pdf

22. Leisinger, K. Corporate Responsibility for Access to Medicines. Journal for Business Ethics; Feb 2009;85 (1):3-23.

23. European Union Green Paper. Promoting a European Framework for Corporate Social Responsibility. . [Internet]. 2002 [cited 2008 April 15] Available at:

http://www.jussemper.org/Resources/Corporate\%20Activity/Resources/greenpaper_en.pdf

24. Karima R, Oshima Y, Yamamoto K. Identification of subjects for Social Responsibility Education at Universities and the present activity of the University of Tokyo. Environ Sci.. 2006; 13 (6):327-337.

25. Dukes G. Accountability of the pharmaceutical industry. Lancet.. 2002;360 (1):1682-1684

26. Nissan, S. A Bitter Pill to Swallow? [date, publisher unknown]. Internet. [cited 2008 May 17] Available at: http://www.innovestgroup.com/pdfs/2003-08-28bitter_pill.pdf

27. PricewaterhouseCoopers' Health Research Institute (2005) Recapturing the vision: Integrity driven performance in the pharmaceutical industry. London: PricewaterhouseCoopers LLP.

\section{Welcome to the $16^{\text {th }}$ ISPW!}
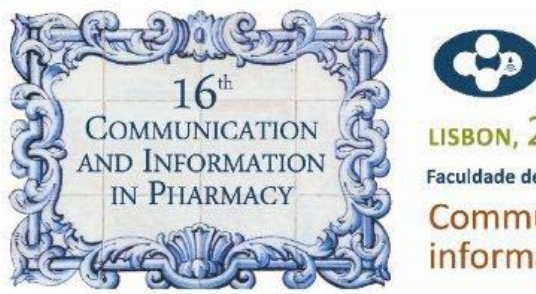

LISBON, 23rd $/ 26^{\text {th }}$ AUGUST 2010

Faculdade de Farmácia da Universidade de Lisboa

Communication and

information in pharmacy

This is a preliminary short announcement for the $16^{\text {th }}$ ISPW

Host Institution and Venue

Faculty of Pharmacy, University of Lisbon, Portugal

Dates

$23^{\text {rd }}$ to $26^{\text {th }}$ August 2010

Key note Speakers and further information soon to be announced at

www.ff.ul.pt/16ISPW

For any inquiries, please use the following email address: 16 ISPW@ff.ul.pt

Hope to have you here in Summer 2010! 